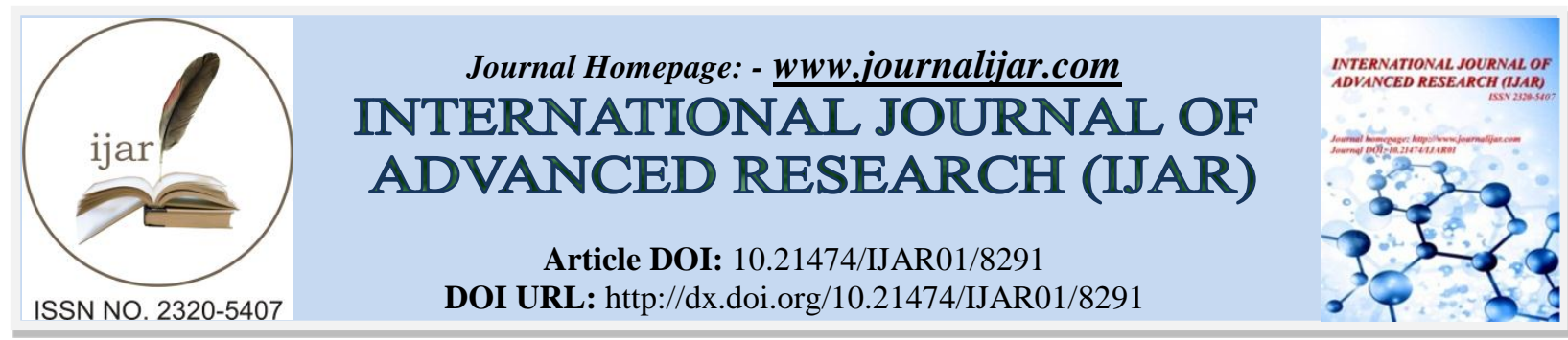

RESEARCH ARTICLE

\title{
AN EMPIRICAL STUDY ON YOUTH PERCEPTION TOWARDS ENTREPRENEURSHIP WITH REFERENCE TO VIJAYAWADA CITY.
}

\author{
Ch.Varalakshmi ${ }^{1}$, N.Srivani ${ }^{1}$ And P.Srinivasa Rao ${ }^{2}$.
}

1. Lecturer,department of mba,andhra loyola college,vijayawada-ap,india.

2. Hod,pg,department of commerceanr college,gudivada-ap india.

\section{Manuscript Info}

Manuscript History

Received: 01 November 2018

Final Accepted: 03 December 2018

Published: January 2019

Keywords:

entrepreneurship,personality

trait,perception.

\begin{abstract}
The research was conducted to exploring the perception of youth towards entrepreneurship. It was the objective of the study on youth perception towards entrepreneurship.It was also aimed at determining the attitude level of youth towards contemporary scenario of the entrepreneurship.The data was collected from one hundred respondents who are from the different academic disciplines and various professionals. The respondents were selected using the stratified random sampling method. Data was collected through pretested questionnaire. Descriptive statements analysis was used to explain and highlight the variables, while statistical tools were applied in the analysis of the relationships existing between variables .

The study concluded that entrepreneurial influencing factors such as personality traits, learning,annual income,family business experiences,economic status of family,government policies, social factors and culture; and entrepreneurial development factors, such as information technology development and education system showing impact on the favourable perception of the youth towards entrepreneurship .
\end{abstract}

Copy Right, IJAR, 2018,. All rights reserved.

\section{Introduction:-}

Entrepreneurship has become an important facet in promoting economic development and wealth. The significance of entrepreneurship has committed extremely in reducing the extent of unemployment and thereby promoting employment opportunities among the youth.The growth and economic sustainability of every nation has been shaped and carved by men and citizens of nation who have taken their destinies in their own hands by perceiving opportunities and risking their resources (money, machines, materials, men) in establishing and operating their own business Entrepreneurship has become a fundamental facet in promoting economic success, steadiness and wealth creation .

The Government of India has undertaken several initiatives and instituted policy measures to foster a culture of innovation and entrepreneurship in the country. Job creation is a foremost challenge facing India. With a significant and unique demographic advantage, India, however, has immense potential to innovate, raise entrepreneurs and create jobs for the benefit of the nation and the world.

Corresponding Author:-Ch.Varalakshmi.

Address:-Lecturer,department of mba,andhra loyola college,vijayawada-ap,india. 
In the recent years, a wide spectrum of new programmes and opportunities to nurture innovation have been created by the Government of India across a number of sectors. From engaging with academia, industry, investors, small and big entrepreneurs, non-governmental organizations to the most underserved sections of society.

Recognising the importance of women entrepreneurship and economic participation in enabling the country's growth and prosperity, Government of India has ensured that all policy initiatives are geared towards enabling equal opportunity for women. The government seeks to bring women to the forefront of India's entrepreneurial ecosystem by providing access to loans, networks, markets and trainings.

\section{Objectives Of The Study}

1. To study the perception of the youth towards entrepreneurship

2. To study the awareness of youth regarding government regulations, schemes,credit facilities related to business

3. To study the different barriers and obstacles faced by entrepreneurs

\section{Research Methodology:-}

The data was collected from primary and secondary sources by using structured questionnaire.The sample was collected by using stratified random sampling technique.

\section{Review Literature}

Entrepreneurship and business creation are a growing alternative for young peoplewhose age group often faces a labour market with double digit unemployment rates.

Traditional career paths and opportunities are disappearing rapidly. A growing number of young people are taking up challenge of starting their own business and much is being learned about how the odds for success can be improved through various types of assistance and through the creation of a supportive environment." (Ulrich Schoof 2006,p.1)

\section{Youth and Entrepreneurship}

In order to investigate youth entrepreneurship and monitor and evaluate policies designed to promote it, a definition of youth entrepreneurship is necessary.Unfortunately there is no generally agreed upon definition of the terms "entrepreneurship", "entrepreneur" or "youth entrepreneurship" in the literature yet.For the purpose of this study, a behaviourally-based definition instead of a trait-based approach is favoured. Thus entrepreneurship is a set of behaviours and an entrepreneur is someone who undertakes these behaviours (Ulrich, 2006). Ulrich explained that using a behavioural definition facilitates the analyses of youth entrepreneurship, as it is easier to observe what young entrepreneurs do and how they do it than to identify their particular "entrepreneurial" traits and qualities suggesting that entrepreneurship is innate, rather than something that can be learned. He further defined entrepreneurship as "the recognition of an opportunity to create value, and the process of acting on this opportunity, whether or not it involves the formation of a new entity. While concepts such as "innovation" and "risk taking" in particular are usually associated with entrepreneurship, they are not necessary to define the term.

\section{Types of (Youth) Entrepreneurship and Young Entrepreneurs}

The two approaches (behavioural based and trait based) each feature strongly in the

literature. The trait-based approach is characterized by attempts to identify entrepreneurial" traits and qualities and is evident, for example, in a definition of entrepreneurship proposed by Schnurr and Newing (1997, cited in Chigunta, 2002 ,

p.1) as the "practical application of enterprising qualities, such as innovation,creativity, and risk-taking into the work environment (either in self- employment or in small start-up firms), using the appropriate skill necessary for success in that environment and culture".Youth entrepreneurship and entrepreneurial activity can occur in different sectors, enterprise types and businesses (branches) and this engagement can have various reasons and motivations. In this section different types of youth entrepreneurship and young entrepreneurs are presented.

\section{Economic, Social and Public Entrepreneurship}

According to the definition presented in the preceding section, entrepreneurship isthe recognition of an opportunity to create value, and the process of acting on this opportunity. For enterprises in the private sector (economic 
entrepreneurship) the main value or outcome is wealth creation and profit generation for those who own the enterprise. As the majority of young and old entrepreneurs engage in entrepreneurship of this type, most of the research and literature focuses on this aspect. Another type of entrepreneurship, gaining popularity across the globe, is social entrepreneurship. Social entrepreneurship uses entrepreneurial activity to create social value; wealth creation is just a means to an end and a way of measuring value creation.As Dees (2001) puts it, "For social entrepreneurs, social mission-related impact becomes the central criterion, not wealth creation".

Another approach to classify different types of young entrepreneurs is a transitionalCategorization, based on significant structural differentiation in youth enterpriseActivities. Studies from different countries suggest that youth entrepreneurship varies according to age. Chigunta (2002) proposes a broad categorization into three (transitional) phases explained below:

Pre-entrepreneurs (in the age of 15-19 years):

This is the formative stage. These younger youth are often in transition from the security of the home oreducation to the work place. But, as Curtain (2000) observes, for many young people, the transition from education to work is not a single step of leaving theeducational system and entering the world of work.

\section{Budding entrepreneurs (in the age of 20-25 years):}

This is the growth stage. Theseyouth are likely to have gained some experience, skills and capital to enable them run their own enterprises. They often face three enterprise pathways:

1. Remaining stuck in marginal activities;

2. Going out of business; and

3. Running successful enterprises.

4. Emergent entrepreneurs (in the age of 26-29 years).

This is the prime stage. Withvaluable experiences in business, emergent entrepreneurs have a higher level of maturity than youth in the lower age groups. Hence they are more likely to run moreviable enterprises than younger people.

However, this kind of categorization can only serve as a broad suggestion, as transitions in the process of youth enterprise development will differ from country to,country and from business sector to business sector. Nonetheless, it becomes obviousthat observing and recognizing the different development stages and transitions (fromschool to business and from work/business to business) is crucial for evaluating and designing appropriate policies and strategies to foster youth entrepreneurship

\section{Data Analysis And Interpretation:-}

\section{Hypothesis:}

H0:Different variables have no impact on youth perception towards entrepreneurship

H1:Different variables have impact on youth perception towards entrepreneurship

Table 1:- Different characteristics of the respondents.

\begin{tabular}{|l|l|l|}
\hline Parameter & No. of investors & Percentage \\
\hline Gender & & \\
\hline Male & $\mathbf{5 0}$ & $\mathbf{5 0}$ \\
\hline Female & $\mathbf{5 0}$ & $\mathbf{5 0}$ \\
\hline Total & $\mathbf{1 0 0}$ & $\mathbf{1 0 0}$ \\
\hline Qualification & & \multicolumn{2}{|l|}{} \\
\hline Graduates & $\mathbf{3 5}$ & $\mathbf{3 5}$ \\
\hline Post Graduates & $\mathbf{3 5}$ & $\mathbf{3 5}$ \\
\hline Professional & $\mathbf{3 0}$ & $\mathbf{3 0}$ \\
\hline Total & $\mathbf{1 0 0}$ & $\mathbf{1 0 0}$ \\
\hline Occupation & & \multicolumn{2}{|l|}{} \\
\hline Students & $\mathbf{7 0}$ & $\mathbf{7 0}$ \\
\hline Self employed & $\mathbf{1 0}$ & $\mathbf{1 0}$ \\
\hline Employed & $\mathbf{2 0}$ & $\mathbf{2 0}$ \\
\hline
\end{tabular}




\begin{tabular}{|c|c|c|}
\hline Total & 100 & 100 \\
\hline \multicolumn{3}{|l|}{ Annual income } \\
\hline 0-1 Lakh & 70 & 70 \\
\hline 1Lakh-3Lakhs & 20 & 20 \\
\hline Above 3Lakhs & 10 & 10 \\
\hline Total & 100 & 100 \\
\hline \multicolumn{3}{|l|}{ Economic status of family } \\
\hline Poor & 20 & 20 \\
\hline Middle class & 70 & 70 \\
\hline Upper middle class & 10 & 10 \\
\hline Total & 100 & 100 \\
\hline \multicolumn{3}{|l|}{$\begin{array}{l}\text { Awareness of respondents about } \\
\text { business }\end{array}$} \\
\hline Low & 35 & 35 \\
\hline Moderate & 35 & 35 \\
\hline High & 30 & 30 \\
\hline Total & 100 & 100 \\
\hline \multicolumn{3}{|l|}{$\begin{array}{l}\text { Awareness of respondents about } \\
\text { credit facilities and government } \\
\text { subsidies }\end{array}$} \\
\hline Low & 35 & 35 \\
\hline Moderate & 35 & 35 \\
\hline High & 30 & 30 \\
\hline Total & 100 & 100 \\
\hline \multicolumn{3}{|l|}{$\begin{array}{l}\text { Awareness of respondents about } \\
\text { business law }\end{array}$} \\
\hline Low & 35 & 35 \\
\hline Moderate & 35 & 35 \\
\hline High & 30 & 30 \\
\hline Total & 100 & 100 \\
\hline \multicolumn{3}{|l|}{$\begin{array}{l}\text { Awareness of respondents about } \\
\text { corporate law }\end{array}$} \\
\hline Low & 35 & 35 \\
\hline Moderate & 35 & 35 \\
\hline High & 30 & 30 \\
\hline Total & 100 & 100 \\
\hline \multicolumn{3}{|l|}{$\begin{array}{l}\text { Awareness of respondents about tax } \\
\text { laws }\end{array}$} \\
\hline Low & 35 & 35 \\
\hline Moderate & 35 & 35 \\
\hline High & 30 & 30 \\
\hline Total & 100 & 100 \\
\hline \multicolumn{3}{|l|}{$\begin{array}{l}\text { barriers and difficulties faced by } \\
\text { respondents }\end{array}$} \\
\hline Lack of capital & 25 & 25 \\
\hline Government rules and regulations & 45 & 45 \\
\hline High interest on bank loans & 10 & 10 \\
\hline Lack of government support & 20 & 20 \\
\hline total & 100 & 100 \\
\hline
\end{tabular}




\section{Chi-square Test:-}

Chi-square is a statistical test commonly used to compare observed data with data we would expect to obtain according to a specific hypothesis

1. H0: There is no relationship between gender and youth perception towards entrepreneurship

2. H1:There is relationship between gender and youth perception towards entrepreneurship

Table 2:-

\begin{tabular}{|c|c|c|c|c|c|}
\hline \multirow{8}{*}{ 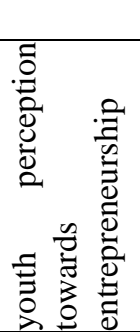 } & & \multicolumn{4}{|l|}{ Gender } \\
\hline & & & MALE & FEMALE & TOTAL \\
\hline & \multirow{2}{*}{ Low } & Count & 25 & 30 & 55 \\
\hline & & Expected count & 27.5 & 27.5 & 55 \\
\hline & \multirow[t]{2}{*}{ Moderate } & Count & 20 & 10 & 30 \\
\hline & & Expected count & 15 & 15 & 30 \\
\hline & \multirow[t]{2}{*}{ High } & Count & 5 & 10 & 15 \\
\hline & & Expected count & 7.5 & 7.5 & 15 \\
\hline \multicolumn{2}{|l|}{$n+a$} & total & 50 & 50 & 100 \\
\hline
\end{tabular}

Table 3:- Chi-square test

\begin{tabular}{|l|l|l|}
\hline & Value & Df \\
\hline Pearson Chi-Square & 4.2417 & 2 \\
\hline N of valid cases & 100 & \\
\hline
\end{tabular}

caluculated value of Chi-Square is 4.2417. Chi-Square value at 5\% significance level and 2 degrees of freedom is 5.991.As caluculated value of Chi-Square is less than the critical value.

Null hypothesis is accepted and alternative hypothesis is rejected,disclosed that there is no relationship between gender and youth perception towards entrepreneurship

1. H0: There is no relationship between educational qualification of the respondent and youth perception towards entrepreneurship

2. H1:There is relationship between educational qualification of the respondent and youth perception towards entrepreneurship

Table 4:-

\begin{tabular}{|c|c|c|c|c|c|c|}
\hline & & Educational qua & ication & & & \\
\hline 竞 & & & Undergraduate & graduate & $\begin{array}{l}\text { Post } \\
\text { graduate }\end{array}$ & TOTAL \\
\hline & Low & Count & 10 & 8 & 5 & 23 \\
\hline$₫ \quad \frac{\pi}{5}$ & & Expected count & 8.05 & 8.05 & 6.9 & 23 \\
\hline$\overline{\bar{\Xi}}$ & Moderate & Count & 20 & 22 & 20 & 62 \\
\hline$y \bar{D}$ & & Expected count & 21.7 & 21.7 & 18.6 & 62 \\
\hline 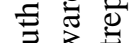 & High & Count & 5 & 5 & 5 & 15 \\
\hline$\stackrel{0}{0} \overline{0}$ & & Expected count & 5.25 & 5.25 & 4.5 & 15 \\
\hline & & total & 35 & 35 & 30 & 100 \\
\hline
\end{tabular}

Table 5:- Chi-square test

\begin{tabular}{|l|l|l|}
\hline & Value & Df \\
\hline Pearson Chi-Square & 1.317 & 4 \\
\hline N of valid cases & 100 & \\
\hline
\end{tabular}


caluculated value of Chi-Square is 1.317. Chi-Square value at 5\% significance level and 4 degrees of freedom is 9.488. As caluculated value of Chi-Square is less than the critical value.

Null hypothesis is accepted and alternative hypothesis is rejected,disclosed that there is no relationship between educational qualification of the respondent and youth perception towards entrepreneurship

1. H0: There is no relationship between occupation of the respondent and youth perception towards entrepreneurship

2. H1:There is relationship between occupation of the respondent and youth perception towards entrepreneurship

Table 6:-

\begin{tabular}{|c|c|c|c|c|c|c|}
\hline & & \multicolumn{5}{|l|}{ occupation } \\
\hline & & & student & $\begin{array}{l}\text { Self } \\
\text { employed }\end{array}$ & employed & TOTAL \\
\hline & \multirow[t]{2}{*}{ Low } & Count & 30 & 0 & 15 & 45 \\
\hline & & Expected count & 31.5 & 4.5 & 9 & 45 \\
\hline & \multirow[t]{2}{*}{ Moderate } & Count & 30 & 4 & 5 & 39 \\
\hline & & Expected count & 27.3 & 3.9 & 7.8 & 39 \\
\hline & \multirow[t]{2}{*}{ High } & Count & 10 & 6 & 0 & 16 \\
\hline & & Expected count & 11.2 & 11.6 & 3.2 & 16 \\
\hline \multicolumn{2}{|l|}{ tis } & total & 70 & 10 & 20 & 100 \\
\hline
\end{tabular}

Table 7:- Chi-square test

\begin{tabular}{|l|l|l|}
\hline & Value & Df \\
\hline Pearson Chi-Square & 16.515 & 4 \\
\hline N of valid cases & 100 & \\
\hline
\end{tabular}

caluculated value of Chi-Square is 16.515. Chi-Square value at 5\% significance level and 4 degrees of freedom is 9.488. As caluculated value of Chi-Square is greater than the critical value.

Null hypothesis is rejected and alternative hypothesis is accepted, disclosed that there is relationship between occupation of the respondent and youth perception towards entrepreneurship

1. H0: There is no relationship between annual income of the respondent and youth perception towards entrepreneurship

2. H1:There is relationship between annual income of the respondent and youth perception towards entrepreneurship

Table 8:-

\begin{tabular}{|c|c|c|c|c|c|c|}
\hline \multicolumn{7}{|c|}{ Annual income } \\
\hline \multirow{7}{*}{ 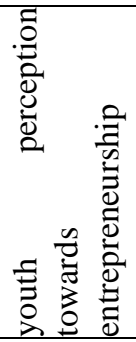 } & & & 0-1 lakh & 1-3 lakhs & $\begin{array}{l}\text { Above } \\
\text { 3lakhs }\end{array}$ & TOTAL \\
\hline & \multirow[t]{2}{*}{ Low } & Count & 35 & 5 & 3 & 43 \\
\hline & & Expected count & 30.1 & 8.6 & 4.3 & 43 \\
\hline & \multirow[t]{2}{*}{ Moderate } & Count & 30 & 10 & 5 & 45 \\
\hline & & Expected count & 31.5 & 4.5 & 9 & 45 \\
\hline & \multirow[t]{2}{*}{ High } & Count & 5 & 5 & 2 & 12 \\
\hline & & Expected count & 8.4 & 2.4 & 1.2 & 12 \\
\hline \multicolumn{2}{|l|}{+2} & total & 70 & 20 & 10 & 100 \\
\hline
\end{tabular}

Table 9:- Chi-square test

\begin{tabular}{|l|l|l|}
\hline & Value & Df \\
\hline Pearson Chi-Square & 15.991 & 4 \\
\hline N of valid cases & 100 & \\
\hline
\end{tabular}


caluculated value of Chi-Square is 15.991. Chi-Square value at 5\% significance level and 4 degrees of freedom is 9.488. As caluculated value of Chi-Square is greater than the critical value.

Null hypothesis is rejected and alternative hypothesis is accepted,disclosed that there is relationship between annual income of the respondent and youth perception towards entrepreneurship

1. H0: There is no relationship between economic status of family of the respondent and youth perception towards entrepreneurship

2. H1:There is relationship between economic status of family of the respondent and youth perception towards entrepreneurship

Table 10:-

\begin{tabular}{|c|c|c|c|c|c|c|}
\hline & & Economic status & f fami & & & \\
\hline 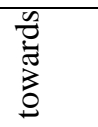 & & & poor & Middle class & $\begin{array}{l}\text { Upper } \\
\text { middle } \\
\text { class }\end{array}$ & TOTAL \\
\hline & \begin{tabular}{|l|} 
Low \\
\end{tabular} & Count & 10 & 20 & 0 & 30 \\
\hline مص & & Expected count & 6 & 21 & 3 & 30 \\
\hline ప & Moderate & Count & 10 & 20 & 5 & 35 \\
\hline एँ & & Expected count & 7 & 24.5 & 2.5 & 35 \\
\hline$\Xi \bar{\partial}$ & \begin{tabular}{|l|} 
High \\
\end{tabular} & Count & 0 & 30 & 5 & 35 \\
\hline$\Xi \Xi$ & & Expected count & 7 & 24.5 & 3.5 & 35 \\
\hline & & total & 20 & 70 & 10 & 100 \\
\hline
\end{tabular}

Table 11:- Chi-square test

\begin{tabular}{|l|l|l|}
\hline & Value & Df \\
\hline Pearson Chi-Square & 18.191 & 4 \\
\hline N of valid cases & 100 & \\
\hline
\end{tabular}

caluculated value of Chi-Square is 18.191. Chi-Square value at 5\% significance level and 4 degrees of freedom is 9.488. As caluculated value of Chi-Square is greater than the critical value.

Null hypothesis is rejected and alternative hypothesis is accepted,disclosed that there is relationship between economic status of the family of the respondent and youth perception towards entrepreneurship

1. H0: There is no relationship between awareness of respondents about business and youth perception towards entrepreneurship

2. H1:There is relationship between awareness of respondents about business and youth perception towards entrepreneurship

Table 12:-

\begin{tabular}{|c|c|c|c|c|c|c|}
\hline & & Awareness of re & ondents abc & iness & & \\
\hline .气̃̄ & & & graduation & $\begin{array}{l}\text { Post } \\
\text { graduation }\end{array}$ & professional & TOTAL \\
\hline$\stackrel{0}{0} \cong$ & Low & Count & 20 & 5 & 5 & 30 \\
\hline$\stackrel{5}{a}$ & & Expected count & 10.5 & 10.5 & 9 & 30 \\
\hline$\overline{\bar{\Xi}}$ & Moderate & Count & 10 & 20 & 15 & 45 \\
\hline$y=$ & & Expected count & 15.75 & 15.75 & 13.5 & 45 \\
\hline 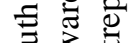 & High & Count & 5 & 10 & 10 & 25 \\
\hline$\therefore 0 \overrightarrow{0}$ & & Expected count & 8.75 & 8.75 & 7.5 & 25 \\
\hline & & total & 35 & 35 & 30 & 100 \\
\hline
\end{tabular}


Table 13:- Chi-square test

\begin{tabular}{|l|l|l|}
\hline & Value & Df \\
\hline Pearson Chi-Square & 19.281 & 4 \\
\hline N of valid cases & 100 & \\
\hline
\end{tabular}

Caluculated value of Chi-Square is 19.281. Chi-Square value at 5\% significance level and 4 degrees of freedom is 9.488. As calculated value of Chi-Square is greater than the critical value.

Null hypothesis is rejected and alternative hypothesis is accepted,disclosed that there is relationship between awareness of respondents about business and youth perception towards entrepreneurship

H0: There is no relationship between awareness of credit facilities and government subsidies from different financial institutions and youth perception towards entrepreneurship

H1: There is relationship between awareness of credit facilities and government subsidies from different financial institutions and youth perception towards entrepreneurship

Table 14:-

\begin{tabular}{|c|c|c|c|c|c|c|}
\hline & & \multicolumn{5}{|c|}{ Awareness of respondents about credit facilities and government subsidies } \\
\hline \multirow{7}{*}{ 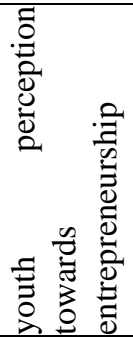 } & & & graduate & $\begin{array}{l}\text { Post } \\
\text { graduate }\end{array}$ & professional & TOTAL \\
\hline & \multirow[t]{2}{*}{ Low } & Count & 30 & 5 & 5 & 40 \\
\hline & & Expected count & 14 & 14 & 12 & 40 \\
\hline & \multirow[t]{2}{*}{ Moderate } & Count & 5 & 25 & 20 & 50 \\
\hline & & Expected count & 17.5 & 17.5 & 15 & 50 \\
\hline & \multirow[t]{2}{*}{ High } & Count & 0 & 5 & 5 & 10 \\
\hline & & Expected count & 3.5 & 3.5 & 3 & 10 \\
\hline \multicolumn{2}{|l|}{+2} & total & 35 & 35 & 30 & 100 \\
\hline
\end{tabular}

Table 15:- Chi-square test

\begin{tabular}{|l|l|l|}
\hline & Value & Df \\
\hline Pearson Chi-Square & 47.18 & 4 \\
\hline N of valid cases & 100 & \\
\hline
\end{tabular}

caluculated value of Chi-Square is 47.18. Chi-Square value at 5\% significance level and 4 degrees of freedom is 9.488. As caluculated value of Chi-Square is greater than the critical value.

Null hypothesis is rejected and alternative hypothesis is accepted,disclosed that there is relationship between awareness of respondents about credit facilities and government subsidies and youth perception towards entrepreneurship

1. H0: There is no relationship between awareness of business law and youth perception towards entrepreneurship

2. H1: There is relationship between business law and youth perception towards entrepreneurship

Table 16:-

\begin{tabular}{|c|c|c|c|c|c|c|}
\hline & & \multicolumn{5}{|c|}{ Awareness of respondents about business law } \\
\hline \multirow{3}{*}{ 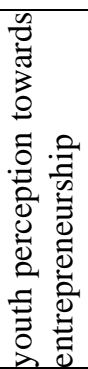 } & & & graduate & $\begin{array}{l}\text { Post } \\
\text { graduate }\end{array}$ & professional & TOTAL \\
\hline & \multirow[t]{2}{*}{ Low } & Count & 30 & 5 & 5 & 40 \\
\hline & & Expected count & 14 & 14 & 12 & 40 \\
\hline
\end{tabular}




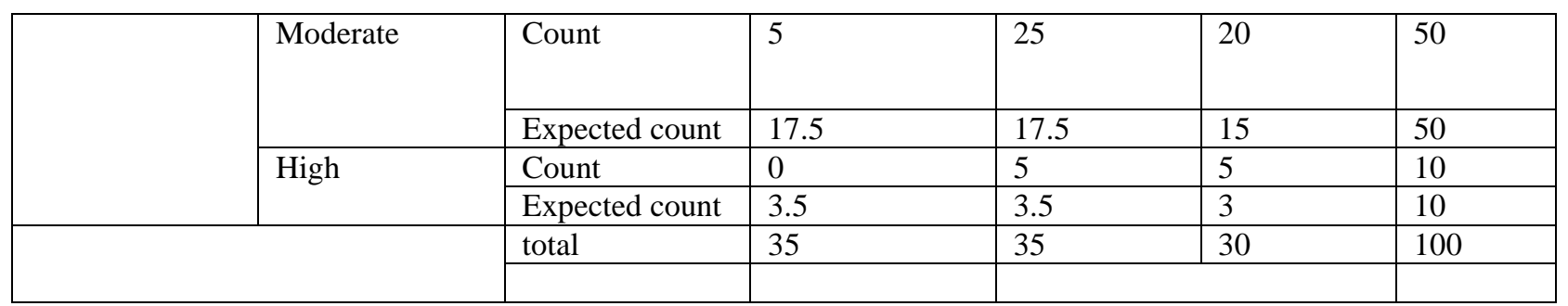

Table 17:- Chi-square test

\begin{tabular}{|l|l|l|}
\hline & Value & Df \\
\hline Pearson Chi-Square & 47.18 & 4 \\
\hline N of valid cases & 100 & \\
\hline
\end{tabular}

caluculated value of Chi-Square is 47.18 . Chi-Square value at $5 \%$ significance level and 4 degrees of freedom is 9.488.As calculated value of Chi-Square is greater than the critical value.

Null hypothesis is rejected and alternative hypothesis is accepted, disclosed that there is relationship between awareness of respondents about business law and youth perception towards entrepreneurship

1. H0: There is no relationship between awareness corporate law and youth perception towards entrepreneurship

2. H1: There is relationship between awareness of corporate law and youth perception towards entrepreneurship

Table 18:-

\begin{tabular}{|c|c|c|c|c|c|c|}
\hline & & \multicolumn{5}{|c|}{ Awareness of respondents about corporate law } \\
\hline \multirow{7}{*}{ 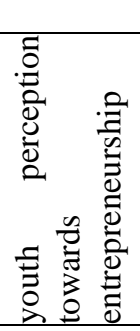 } & & & Low & Moderate & high & TOTAL \\
\hline & \multirow{2}{*}{ Low } & Count & 20 & 26 & & 46 \\
\hline & & Expected count & 21.16 & 24.84 & & 46 \\
\hline & \multirow[t]{2}{*}{ Moderate } & Count & 10 & 16 & & 26 \\
\hline & & Expected count & 11.96 & 14.04 & & 26 \\
\hline & \multirow[t]{2}{*}{ High } & Count & 16 & 12 & & 28 \\
\hline & & Expected count & 12.88 & 15.12 & & 28 \\
\hline \multicolumn{2}{|l|}{ (n) } & total & 46 & 54 & & 100 \\
\hline
\end{tabular}

Table 19:- Chi-square test

\begin{tabular}{|l|l|l|}
\hline & Value & Df \\
\hline Pearson Chi-Square & 47.18 & 4 \\
\hline N of valid cases & 100 & \\
\hline
\end{tabular}

caluculated value of Chi-Square is 47.18 . Chi-Square value at 5\% significance level and 4 degrees of freedom is 9.488.As caluculated value of Chi-Square is greater than the critical value.

Null hypothesis is rejected and alternative hypothesis is accepted,disclosed that there is relationship between awareness of respondents about corporate law and youth perception towards entrepreneurship

1. H0: There is no relationship between awareness of tax laws and youth perception towards entrepreneurship

2. H1: There is relationship between awareness tax laws and youth perception towards entrepreneurship

Table 20:-

\begin{tabular}{|c|c|c|c|c|c|c|}
\hline \multicolumn{2}{|l|}{ (2) } & \multicolumn{5}{|c|}{ Awareness of respondents about tax laws } \\
\hline \multirow{5}{*}{ 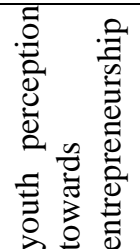 } & & & graduate & $\begin{array}{l}\begin{array}{l}\text { Post } \\
\text { graduate }\end{array}\end{array}$ & professional & TOTAL \\
\hline & \multirow[t]{2}{*}{ Low } & Count & 30 & 5 & 5 & 40 \\
\hline & & Expected count & 14 & 14 & 12 & 40 \\
\hline & \multirow[t]{2}{*}{ Moderate } & Count & 5 & 25 & 20 & 50 \\
\hline & & Expected count & 17.5 & 17.5 & 15 & 50 \\
\hline
\end{tabular}




\begin{tabular}{|l|l|l|l|l|l|l|}
\hline \multirow{2}{*}{ High } & Count & 0 & 5 & 5 & 10 \\
\cline { 3 - 7 } & Expected count & 3.5 & 3.5 & 3 & 10 \\
\hline \multirow{2}{*}{} & total & 35 & 35 & 30 & 100 \\
\cline { 2 - 6 } & & & & & \\
\hline
\end{tabular}

Table 21:- Chi-square test

\begin{tabular}{|l|l|l|}
\hline & Value & Df \\
\hline Pearson Chi-Square & 47.18 & 4 \\
\hline N of valid cases & 100 & \\
\hline
\end{tabular}

caluculated value of Chi-Square is 47.18. Chi-Square value at 5\% significance level and 4 degrees of freedom is 9.488. As caluculated value of Chi-Square is greater than the critical value.

Null hypothesis is rejected and alternative hypothesis is accepted,disclosed that there is relationship between awareness of respondents about tax law and youth perception towards entrepreneurship

1. H0: There is no relationship between awareness of corporate law and youth perception towards entrepreneurship

2. H1: There is relationship between awareness corporate law and youth perception towards entrepreneurship

Table 22:-

\begin{tabular}{|c|c|c|c|c|c|c|}
\hline & & \multicolumn{5}{|c|}{ Awareness of respondents about corporate law } \\
\hline \multirow{8}{*}{ 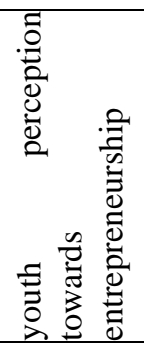 } & & & graduate & $\begin{array}{l}\text { Post } \\
\text { graduate }\end{array}$ & professional & TOTAL \\
\hline & \multirow[t]{2}{*}{ Low } & Count & 30 & 5 & 5 & 40 \\
\hline & & Expected count & 14 & 14 & 12 & 40 \\
\hline & \multirow{2}{*}{ Moderate } & Count & 5 & 25 & 20 & 50 \\
\hline & & Expected count & 17.5 & 17.5 & 15 & 50 \\
\hline & \multirow[t]{3}{*}{ High } & Count & 0 & 5 & 5 & 10 \\
\hline & & Expected count & 3.5 & 3.5 & 3 & 10 \\
\hline & & total & 35 & 35 & 30 & 100 \\
\hline
\end{tabular}

1. H0: There is no relationship between barriers and difficulties faced by respondents to commence new business and youth perception towards entrepreneurship

2. H1: There is relationship between barriers and difficulties faced by respondents to commence new business and youth perception towards entrepreneurship

Table 23:-

\begin{tabular}{|c|c|c|c|c|c|c|c|}
\hline \multirow[b]{2}{*}{ 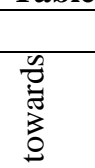 } & \multicolumn{7}{|c|}{ barriers and difficulties faced by respondents } \\
\hline & & & $\begin{array}{l}\text { Lack of } \\
\text { capital }\end{array}$ & $\begin{array}{l}\text { Government } \\
\text { rules and } \\
\text { regulations }\end{array}$ & $\begin{array}{l}\text { High } \\
\text { interest on } \\
\text { bank loans }\end{array}$ & $\begin{array}{l}\text { Lack of } \\
\text { government } \\
\text { support }\end{array}$ & Total \\
\hline \multirow{6}{*}{ 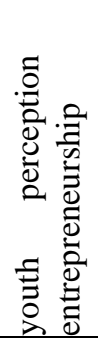 } & \multirow[b]{2}{*}{ Low } & Count & 8 & 15 & 2 & 0 & 25 \\
\hline & & Expected count & 6.25 & 11.25 & 2.5 & 5 & 25 \\
\hline & \multirow[t]{2}{*}{ Moderate } & Count & 9 & 20 & 5 & 15 & 49 \\
\hline & & Expected count & 12.25 & 22.05 & 4.9 & 9.8 & 49 \\
\hline & \multirow[t]{2}{*}{ High } & Count & 8 & 10 & 3 & 5 & 26 \\
\hline & & Expected count & 6.5 & 11.7 & 2.6 & 5.2 & 26 \\
\hline 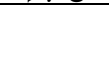 & & total & 25 & 45 & 10 & 20 & 100 \\
\hline
\end{tabular}


Table 24:- Chi-square test

\begin{tabular}{|l|l|l|}
\hline & Value & Df \\
\hline Pearson Chi-Square & 11.336 & 6 \\
\hline N of valid cases & 100 & \\
\hline
\end{tabular}

calculated value of Chi-Square is 11.336. Chi-Square value at 5\% significance level and 6 degrees of freedom is 12.592.As calculated value of Chi-Square is greater than the critical value.

Null hypothesis is accepted and alternative hypothesis is rejected, disclosed that there is no relationship between barriers and difficulties faced by respondents to commence new business and youth perception towards entrepreneurship

\section{Findings}

1. In this study different demographical factors had taken. The following results were found that both men and women are perceiving the entrepreneurial opportunities in similar manner, irrespective of the educational qualification of the respondent they want prefer entrepreneurship as their career. Other factors such as economic status, occupational status, annual income influencing the perceived opinion of the youth towards entrepreneurship.

2. The literacy of the respondents about different issues such as business opportunities, credit facilities and government subsidies, corporate law, business law, securities laws, taxation laws, barriers to opt entrepreneurship are influencing the perceived opinion of the youth towards entrepreneurship.

\section{Conclusion:-}

In India job seekers are more compared to job creators, so the country need entrepreneurs, even the government is encouraging youth,women by offering different types of credit facilities,subsidies,so India need good entrepreneurs from the youth. 